\title{
10. Reflections on A Remarkable Journey
}

\section{Carol Kidu}

My autobiography A Remarkable Journey is not a political life story - it is a love story that intertwines with politics because it is about the challenges of learning to live in a culture that is very different from my culture of birth, and about my life story that provided a foundation for my entry into politics. It also superficially documents political events that prompted me to contest an election in spite of the fact that I knew very little about politics.

A Remarkable Journey was written as part of the grieving process after the death in January 1994 of my husband, Sir Buri Kidu, and as a tribute to an extraordinary man who died too young. Buri's death from a sudden heart attack six months after his non-reappointment as Chief Justice of Papua New Guinea was attributed to the politics of the time by many commentators. At the cultural level, many family members attributed Buri's death to sorcery instigated and paid for by certain politicians who feared Buri. It was an extremely emotionally charged time in my life and that of my extended family. Thus I wrote as a release of emotions and wrote, from an emotional and very personal perspective, a story that I felt needed to be told. I wrote from the heart.

In reality, I did not write for publication completely of my own volition because a publisher I had met while writing social science textbooks for the curriculum unit of the Department for Education had been encouraging me for a long time to write my story. He eventually convinced me to continue the manuscript that I had started after Buri's death and which was planned to finish with his death. He and the publishers, Pearson Education, had to convince me to make it my story rather than Buri's story and to finish the story with my election into politics. My mother also repeatedly asked me if I was ever going to finish 'the book' and thus during December 2000, when visiting my mother for Christmas, I resumed what was to become an arduous task of researching, recording, rechecking, cross-referencing and acknowledging photographic materials to produce the final manuscript.

Thus my full political life story (as yet unwritten) started from a point of anger - extreme anger and frustration about politics and personalities. Other than the circumstances surrounding Sir Buri's non-reappointment as Chief Justice and the concluding chapter which covers my entry into politics and my first 
political campaign, my political life story remains untold - a task for the future perhaps - but a task that I know will not be easy because writing quite simply, although often pleasurable, is usually not easy and is very time-consuming.

Perhaps with a team of research assistants the task would not be so daunting , but it will still be difficult if it is to be a personal account rather than a documented political history of that 15 years of our nation's political history. A personal account can be exhausting and contentious, as was my experience with $A$ Remarkable Journey - exhausting emotionally because it opens old wounds and because a personal account of historical events is, in essence, subjective and thus open to potential challenge.

Perhaps the hardest aspect of writing A Remarkable Journey was the issue of what to include and how to say it. It was an agonising process and I used one of my children as the initial 'editor' of content. Her advice was not necessarily useful regarding my early life in PNG and learning to live in Motu society: 'Say it as it was'; 'Don't avoid the hard stuff'; 'Take off the rose-tinted glasses'. My autobiography was very frank and personal but also cautious in content. I was fortunate in that there were no major issues when it came to editing and the publishers took a very flexible approach in the interactive editorial process. Only one issue was not to my liking but was insisted on by the editors, and that was the choice of title for the book.

My title choice was Never Ask Me to Choose because those were Buri's words when we discussed marriage. He said, 'Never ask me to choose between you and my people because I will not choose you, I will choose my people.' It was one of the most significant statements made to me in my whole adult life and in some ways the basis of all that was to follow. However, the editors insisted that it was not a marketable book title and gave me three choices, which eventually narrowed down to A Remarkable Journey. I still believe my title was a better one!

The launch of A Remarkable Journey was a low-key event bringing Buri's family together in the lead-up to the 2002 election to acknowledge their important role in my life.

The only open negative reaction to the book came in a letter from a grandson of one of the missionaries in Buri's early life who took offence to the way that section was written and felt it insulted his grandfather. It came as a surprise to me because definitely no insult had been intended. I simply wrote anecdotes that Buri had told me about his memories of his early life. In retrospect I realise that the particular anecdotes could be interpreted as negative reflections but I retold them because they illustrated Buri's leadership qualities and his courage to defend what he saw as right and wrong even in circumstances of authority. 
Undoubtedly there are people who do not accept my interpretation of the events surrounding Sir Buri's non-reappointment as Chief Justice but, if they have ever read the book, they have chosen not to comment.

One thing that has surprised me is that some young Papua New Guineans have thanked me for writing the book, saying that it helped them to understand and analyse the tensions in their own lives while growing up in two worlds. This is a reaction that I find particularly rewarding personally.

Similarly some non-Papua New Guineans have said that it has helped them to understand Papua New Guinea better. Other than that, there has been little reaction to the book which concluded with my election into Parliament.

'Geez, Mum, you've really got yourself into deep shit this time.'

'Shut up Basil,' I hissed between closed teeth.

Basil dozed beside me - slightly intoxicated after a sleepless night following the results with the tally team in the village. It was 1997, at the end of a very strategically planned and exhausting campaign, when word came to the village that the Returning Officer would declare the seat that morning. Basil had decided to accompany me to the counting room. Celebrations were already starting outside the family house in Pari village as we squeezed into the tiny Suzuki that had become my trademark during the campaign. The singing and dancing had begun as I left for the declaration. I forced myself to dance and smile with young Dadi who had diligently checked the Common Roll for the names of our supporters for weeks before the voting day. I was smiling on the outside but inside my heart was heavy - burdened by the enormity of what I had done and the implications carried with it.

'Geez, Mum, you've really got yourself into deep shit this time.' Basil roused beside me and continued like a broken record.

'Basil!!' I hissed again. 'Stop it or go outside.'

Only time would tell how deep that shit would be. But that's another story. These were the last two sentences of A Remarkable Journey. which acknowledged that the book was a task unfinished. Quite a number of people have asked me when I am going to write the next part of the story but, until now, it has remained a task on my 'to do one day' list.

On several occasions during my political career, a senior employee of Macmillan asked me to write my story. He first contacted me after the Australian Broadcasting Corporation (ABC) covered my life in a television documentary called Australian Story. I responded that I had already written a book, which he subsequently read, but he continued to encourage me to write the whole 
story starting from the beginning again and including my life in politics. It is something that I wanted to do but at that time, as a government minister, did not (and still do not) have the time to do, and I am not willing to work with a ghost writer on something so personal. I guess I may have missed the opportunity to have a publisher waiting for my manuscript but I explained to him when I met him that I am actually struggling not only with time but also with how to structure the book. He said just start at the beginning and write until the end. But I am still not comfortable with that.

Should I do a chronological autobiography? Or should I structure it around issues? Or should I write an autobiography that is a composite of many stand-alone stories within a total story? There is so much when I start thinking about it that it becomes overwhelming. What will interest people? Who is my main target audience? Why would I write another book? Certainly it would not be to make money. My returns from A Remarkable Journey soon made it clear to me that most writers struggle financially and it would not be a viable income option to meet my financial requirements if I continue to live with my large extended family.

I want to write again but then again ...

I think of the workload involved: the content research, the searches for illustrations, the hours of drafting and redrafting as I agonise over the most appropriate way to express something, and becoming a self-appointed editor of my own work! Or should I do an autobiography that is also a biography and ask others such as my children and colleagues to contribute sections to make up the composite story?

I would not call myself a politician by choice but rather by circumstance. I knew nothing about politics - in fact I had never voted until I voted for myself as candidate. I was a teacher by profession and a village wife who had been widowed three years before I stood for my first election. I had met my husband when I was 16 years old - a grade 11 student. We met at a school holiday fitness camp. I was there with two girlfriends and he was there with a group of students from Papua New Guinea who were attending schools in Australia on colonial scholarships. Little did I realise where my first teenage romance would lead me - on a journey to the unexpected.

Was it worth it? That's a question sometimes asked of me. One positive personal outcome in each campaign was a dramatic loss in weight - no need for dieting. The adrenaline flow and constant pressure cooker campaigning - same messages but different delivery in different communities - setting up, packing up and moving on to another community undoubtedly led to the weight loss which was counterbalanced by more wrinkles and more grey hairs and complete and utter 
exhaustion. At the end of each day, late at night, I returned to sleep in the back room of the family village house with the 'golden girls' - the wonderful widows who had been inspired that a widow like them could challenge the norm and succeed. They sat around me talking in hushed whispers as I slept on the floor exhausted, rejuvenating myself for yet another day. They made it their personal duty to protect me from any possibility of evil sorcery invading my space in the darkness.

In the next room male elders kept vigil - and the young women served a constant supply of tea and flour cooked in a variety of ways. During my 2002 campaign, a campaign team leader complained that the elders were eating too much and should go to their own houses. I was horrified - no way would I let that happen. While the elders were there ensuring that all things were done properly to keep the spiritual world at peace I knew that I would win. They were my confidence and each day at least one elder travelled with me into different communities irutauna baine namo daini (to maintain good karma and a good relationship with the spiritual world).

Was it worth it? I ensured that each campaign was an educational opportunity for people - a stocktake of what I had done and what I would try to do in the next five years. In 2007 I was very aware that two rival candidates were using a lot of money in communities while campaigning. How could I counteract the power of money in poor communities? I needed to put something into people's hands that could not be seen as bribery, so we produced a 'bag of knowledge' for each household in my base areas: thousands of colourful plastic bags from Chinese stores (except in my two major bases where women sewed the bags out of calico and youth screen-printed them) and thousands of leaflets about the work I had done - the new laws and policies, colouring books about malaria with coloured pencils, balloons etc. I wanted to put a condom into each bag because of my advocacy on HIV but the campaign team said no to that, not allowing me to push the barriers in conservative communities.

My rationale for the 'bags of knowledge' was that, even if I did lose, something worthwhile would have been achieved by my campaign. Was it worth it? I think so. But would I do it again? No way! As I watched my colleagues prepare for their 2012 campaigns, I felt such a relief that I had chosen not to stand again.

In 1997 I stood as an Independent. After declaration, winning candidates were being whisked away by political parties to gather the numbers into 'camps' to form government. I was declared early in the 109 seats so I chose to visit my mother to avoid all the horse-trading that is part of politics PNG style. When I returned, the winners were in two main camps with a few stragglers 
Political Life Writing in the Pacific

like me who were unwilling to be 'camped in'. All I could do was to look for people whom I thought I could identify with so I decided to join the Opposition and entered the Opposition caucus room.

I have never been conscious of my gender. I had married a man who was very proud of his Melanesian heritage but also a liberated man who had been educated in Australia in the era of the women's liberation movement. I did not anticipate the welcome I would receive when I entered the caucus room.

The Opposition Leader acknowledged me with the comment: 'People in this House wear pants not skirts.' He was a friend of my late husband but uncomfortable about my presence in the sacred modern men's house where there had not been a woman for 10 years before 1997. I smiled and sat down.

The next day, I dressed in a trouser suit and made sure that most men were already present before I entered the caucus room. With a cheeky smile, I stood to attract their attention then kicked one leg in the air to display my trousers. 'Am I welcome now?' I joked with the leader. My point was made. A small act of defiance but delivered with a smile - I knew that direct confrontation with my male colleagues would be counterproductive, a waste of energy. I had to learn how to operate in an environment that was uncomfortable about female participation. But, after 15 years, I felt that I had become like a piece of the furniture at Parliament. I had become comfortable with my male colleagues, and trust that the feeling was mutual.

Would readers be interested in this anecdotal approach to my political life story? Certainly it would probably seem superficial and frivolous to serious political commentators, but what size audience is there for a serious detailed political story? And in view of the fact that I have not kept detailed diaries of my political career, the research required for such an approach to writing would be enormous but certainly not impossible.

One definite reason to write again is that it would give me the opportunity to outline the policy and legislative reforms that I pursued as a Minister and why I pursued them. It would also provide the opportunity to highlight several other major changes in the social sector that were initiated by me; but as they evolved they became owned by my male colleagues for a variety of reasons, as is the case in politics. Would this be cynically viewed as self-promotion and retrospective justification? However, in a nation where there are still not enough women in politics and the role and even the capacity of women is still questioned, it is important to make sure that what women can achieve is documented and acknowledged. To write again would also give me the opportunity to correct 
some of the misperceptions about some of the work I initiated and issues that I pursued. But would people be interested in that or would it simply be writing for myself?

Would I write about the complexity of being a politician in Papua New Guinea, the political culture, the expectations of the general population, the frustrations of trying to negotiate through the system to make sustainable achievements and how those achievements inevitably lead to a whole new set of challenges? On top of all of this, a politician in PNG has to also be an ad hoc project supervisor in the electorate to ensure that their projects comply with guidelines to avoid allegations of corruption and investigation. The struggle to be an effective parliamentarian as well as an effective electorate representative is a constant struggle for politicians in Papua New Guinea. The workload for a conscientious person can be overwhelming, and thus the support systems for politicians are critical but not always available and appropriate. Would such issues be of interest to the general reader?

My decision to retire from politics by not contesting the 2012 election was actually made in 1997 when I told my supporters that if the people allowed me I would serve for three terms maximum. I knew that 15 years would take me into my early 60s and I also knew that I did not want to finish my working life as a politician.

In fact, to serve more than one term in politics in Papua New Guinea is not the norm with over 50 per cent turnover in every election since independence. To serve three terms has been a great privilege but definitely enough. Yes, I left some tasks I had set myself unfinished, but I had made varied inroads on other issues that were not part of my original agenda. Yes, I left politics at a time when I was becoming more efficient at achieving my parliamentary goals, but balancing one's parliamentary agenda with the electorate's expectations is a constant and exhausting juggling act. There are simply not enough hours in the day.

After my first successful campaign in 1997, my daughter gave me a Bird of Paradise ring. My wedding ring had been lost (stolen?) several years earlier so I symbolically put the Bird of Paradise on my marriage ring finger. I was well aware of the fact that my choice to enter politics was a huge commitment and that I was basically marrying myself to the nation. Unfortunately, however, my choice also had a huge impact on my children. I did not have a wife to ensure that all the domestic chores were done and extended family obligations observed. The fact is that politics did affect the lives of my children and I could not have managed without them to attend to all the family matters. 
In addition to having to take on many family tasks to support me, they also had to contend with the fact that often the general public assume that the children of politicians live a privileged life with unlimited access to money. They often had to contend with anger from people who asked for, then demanded money from them. The girls also had to make endless pots of tea and refreshments to feed people who visited unannounced in the hope that I could solve their problems for them. And then the boys would be expected to drive the unexpected visitors back to their community because we live on traditional land away from any bus routes. They were patient with my politics but also very glad when the time for my retirement came close, making it very clear that enough was enough when people began urging me to stand again.

When the swearing in of the new government occurred, I felt a surge of pleasure when the public gallery and the other MPs clapped for each of the three women when they were sworn in. At last, the image of one white woman in parliament had been broken and the nation was proud to have three Melanesian women in the Chamber of Parliament. It was time to take off the Bird of Paradise ring! But what would replace it?

I had the replacement ring ready - a butterfly ring. After 20 years as a teacher and 15 years as a politician - a total of 35 years in public service earning a regular fortnightly income - I was now entering into new territory. I wanted to enter the world of consulting; I also wanted to transform my family home on traditional land at the beach into an income-generating business to help support the family; I wanted to perhaps continue being part of the regional and global lobby for human rights, equity, justice and peace at all levels of society; and I wanted to perhaps work to facilitate transformative change at community level. I wanted to ...

Goodness, where is the space for retirement? So I have set a new target of five more years' hard work to be followed by the luxury of retirement. But that five years will require reinventing myself to some degree - a period of transformation as I learn the ways of life outside the public sector.

And thus I now wear the butterfly ring (a little too tight) to remind myself that during the process of metamorphosis that I have now entered I will face many challenges that I will have to manage. Clearly, at my age, I cannot transform into a beautiful butterfly but the imagery and fantasy will hopefully help me weather the storms still to come in my life.

Will I write another book? I think so. I want to. But I still feel the need for reflective distance before I am ready to begin the task and I definitely need some quiet space in my life - a luxury that I have not yet achieved. But that is another story. 
This text is taken from Political Life Writing in the Pacific:

Reflections on Practice, edited by Jack Corbett and Brij V. Lal, published 2015 by ANU Press, The Australian National University, Canberra, Australia. 